\title{
Oxidative stress and hepatic carcinogenesis: new insights and applications
}

\author{
Hermann M. Bolt $\cdot$ Jan G. Hengstler
}

Published online: 20 January 2010

(C) Springer-Verlag 2010

Hepatocellular carcinoma is the third most common cause of cancer-related deaths worldwide, with about 600,000 patients dying from the disease annually. In $70-90 \%$ of cases, the disease develops on the background of chronic liver cirrhosis or inflammation. In regions with a high prevalence, the majority of cases are related to hepatitis B or C infections. In developed countries, high consumption of alcohol as well as non-alcoholic fatty liver disease appears as main cause (Schütte et al. 2009). This has led to a continued interest in mechanisms of the multistep hepatic carcinogenesis, both from clinical (Ogawa 2009) and experimental (Kudo 2009) points of view. The scientific development is supported by the use of new technologies (Uehara et al. 2008). A pathogenetic principle underlying to various mechanisms involved in hepatocarcinogenesis is the release of free radicals and initiation of oxidative stress (Muriel 2009; Kawai et al. 2010). This applies to indirect genotoxicity, cell proliferation, fibrogenesis and chronic inflammation. There is intensive recent research into antioxidant mechanisms, and a distinct focus is on effective natural compounds. The present array of this research stretches from nutrition to ethnic pharmacology (Vásquez-Garzón et al. 2009; Janani et al. 2009). Recent developments were highlighted in Editorials of Archives of Toxicology (Hengstler and Bolt 2007, 2008).

In this issue of the Archives, the group of Kunitoshi Mitsumori (Tokyo) presents two articles along this line.

H. M. Bolt $(\bowtie) \cdot$ J. G. Hengstler

Leibniz Research Centre for Working Environment and Human Factors (IfADo),

Leibniz Institut für Arbeitsforschung an der TU Dortmund,

Ardeystrasse 67, 44139 Dortmund, Germany

e-mail: bolt@ifado.de
Using the diethylnitrosamine-piperonyl butoxide rodent model (Kawai et al. 2009), it is demonstrated that the pesticide synergist piperonyl butoxide generates reactive oxygen species. Even without apparent induction of oxidative DNA damage, effects such as activation of cell growth and increase of c-Myc- and E2F1- related pathways are being noted, which is put into a perspective to the tumourpromoting properties of the compound (Kawai et al. 2010).

Another hepatic tumour promotor, acting through oxidative stress, is the anthelmintic drug oxfendazole. Nishimura et al. (2010) demonstrate that this effect is counteracted by oral administration of the endogenous antioxidant melatonin and of enzymatically modified isoquercitrin, which is derived from the natural plant antioxidant rutin. It is concluded that reactive oxygen species, generated through the activation of CYP enzymes, are an important factor contributing to the oxfendazole-induced liver tumour promotion. Especially, the enzymatically modified isoquercitrin effectively inhibits these effects and therefore appears to have preventive potential against hepatic carcinogenicity.

This provides another example for modern links between basic research in experimental toxicology and potential clinical application.

\section{References}

Hengstler JG, Bolt HM (2007) Induction and control of oxidative stress. Arch Toxicol 81:823-824

Hengstler JG, Bolt HM (2008) Oxidative stress: from modification of cell-cycle related events, secondary messenger function, dysregulation of small GTPases, protein kinases and phosphatases to redox-sensitive cancer models. Arch Toxicol 82:271-272

Janani P, Sivakumari K, Geetha A, Ravisankar B, Parthasarathy C (2009) Chemopreventive effect of bacoside A on N-nitrosodiethylamine-induced hepatocarcinogenesis in rats. J Cancer Res Clin Oncol. doi:10.1007/s00432-009-0715-0 
Kawai M, Saegusa Y, Jin M, Dewa Y, Nishimura J, Harada T, Shibutani M, Mitsumori K (2009) Mechanistic study on hepatocarcinogenesis pf piperonyl butoxide in mice. Toxicol Pathol 37:761-769

Kawai M, Saegusa Y, Dewa Y, Nishimura J, Kemmochi S, Harada T, Ishii Y, Umemura T, Shibutani M, Mitsumori K (2010) Elevation of cell proliferation via generation of reactive oxygen species by piperonyl butoxide contributes to its liver tumor promoting effects in mice. Arch Toxicol 84 (this issue)

Kudo M (2009) Multistep human hepatocarcinogenesis: correlation of imaging and pathology. J Gastroenterol 44(19):112-118

Muriel P (2009) Role of free radicals in liver diseases. Hepatol Int 3:526-536

Nishimura J, Saegusa Y, Dewa Y, Jin M, Kawai M, Kemmochi S, Harada T, Hayashi S, Shibutani M, Mitsumori K (2010) Antioxidant enzymatically modified isoquercitrin supplementation reduces oxidative stress-related hepatocellular tumor-promotion of oxfendazole in rats. Arch Toxicol 84 (this issue)

Ogawa K (2009) Molecular pathology of early stage chemically induced hepatocarcinogenesis. Pathol Int 59:605-622

Schütte K, Bornschein J, Malfertheimer P (2009) Hepatocellular carcinoma-epidemiological trends and risk factors. Dig Dis 27:80-92

Uehara T, Hirode M, Ono A, Kiyosawa N, Omura K, Shimizu T, Mizukawa Y, Miyagishima T, Nagao T, Urushidani T (2008) A toxicogenomics approach for early assessment of potential nongenotoxic hepatocarcinogenicity of chemicals in rats. Toxicology 250:15-26

Vásquez-Garzón VR, Arrellanes-Robledo J, García-Román R, Aparicio-Rautista DI, Villa-Trevino S (2009) Inhibition of reactive oxygen species and pre-neoplastic lesions by quercetin through an antioxidant defence mechanism. Free Radic Res 43:128-137 